\title{
Antibacterial activity of Ethanol Extract of Purple Passion Fruit Pericarp (Passiflora edulis Sims) on Staphylococcus aureus and Escherichia coli
}

\author{
Sony Eka Nugraha*, Suryadi Achmad, Erly Sitompul \\ Department of Pharmaceutical Biology, Faculty of Pharmacy, Universitas Sumatera Utara, Medan \\ 20155, Indonesia
}

\begin{abstract}
North Sumatera is the central production of purple passion fruit in Indonesia. Passion fruit was processed into beverage product hence resulting passion fruit pericarp waste. The passion fruit pericarp has potential effect as a sources of medicine which is need to be examined such as its antibacterial effect. The purpose of this study was to determine the phytochemical screening and antibacterial activity of ethanol extract of purple passion fruit pericarp against Staphylococcus aureus and Escherichia coli. The extraction was conducted by percolation method using $96 \%$ ethanol. The antibacterial activity against Staphylococcus aureus and Escherichia coli was perfoem using agar diffusion method with paper discs.Phytochemical screening simplicia and ethanol extract showed the presence of flavonoid, glycoside, saponin, tannin and steroid/triterpenoid.The antibacterial activity test showed that the ethanol extract has an effective inhibition at the concentration of 300 $\mathrm{mg} / \mathrm{ml}$ against Staphylococcus aureus and Escherichia coli, it showed dose dependent manner.
\end{abstract}

Keywords: Passiflora edulis Sims, antibacterial, passion fruit pericarp, Staphylococcus aureus and Escherichia coli

\begin{abstract}
Abstrak. Sumatera Utara merupakan salah satu daerah sentral produksi markisa ungu di Indonesia. Pemanfaatan kulit buah markisa perlu dikaji agar dapat berguna antara lain sebagai bahan baku sediaan obat antibakteri. Penelitian ini bertujuan untuk mengetahui golongan senyawa metabolit sekunder dan aktivitas antibakteri dari ekstrak etanol dan fraksi-fraksi kulit buah markisa ungu terhadap bakteri Staphylococcus aureus dan Escherichia coli. Serbuk simplisia diskrining fitokimia kemudian ekstraksi secara perkolasi menggunakan pelarut etanol $96 \%$ lalu dilanjutkan dengan proses fraksinasi dan dilakukan uji aktivitas antibakteri terhadap bakteri Staphylococcus aureus dan Escherichia coli menggunakan metode difusi agar dengan cakram kertas. Skrining fitokimia serbuk simplisia dan ekstrak etanol menunjukkan adanya kandungan flavonoid, glikosida, saponin, tanin dan steroid/triterpenoid. Hasil uji aktivitas antibakteri menunjukkan bahwa ekstrak etanol memberikan aktivitas antibakteri yang efektif pada konsentrasi $300 \mathrm{mg} / \mathrm{ml}$ pada bakteri Staphylococcus aureus dan Escherichia coli, hasil yang diperoleh menunjukan peningkatan efek sering peningkatan dosis.
\end{abstract}

Kata kunci : Passiflora edulis Sims, antibakteri, kulit buah markisa ungu, Staphylococcus aureus and Escherichia coli

Received 14 September 2018 | Revised 12 October 2018 | Accepted 26 November 2018

\footnotetext{
*Corresponding author at: Department of Pharmaceutical Biology, Faculty of Pharmacy, Universitas Sumatera Utara, Padang Bulan, Medan 20155, Indonesia

E-mail address: sonyekanugraha@usu.ac.id
} 


\section{Introduction}

Indonesia as a tropical country has a wide variety of plants that can be used in human life such as herbal medicine. Indonesian has been known and use medicinal plants to heal various health problems, a long before modern health services and modern medicines touch the community. The utilization of traditional herbal medicine in Indonesia was a part of the nation's culture and it is widely used by the community The effectiveness and safety of traditional medicine have not been fully known yet. Natural resources of medicinal materials and traditional medicines are national assets that need to be explored, researched, developed and optimized for their utilization in community.

Purple passion fruit contains various kinds of phytochemical properties. Purple passion fruit leaves contain glycosides, tannins, flavonoids, saponins and alkaloids. Purple passion fruit stems contain glycosides, flavonoids, saponins and alkaloids, while fruits contain glycosides, tannins, flavonoids and alkaloids [1]. The previous study reported that methanol extract of purple passion fruit leaves had antibacterial activity against several bacteria such as Staphylococcus aureus, Staphylococcus faecalis, Bacillus subtilis, Escherichia coli, Proteus vulgaris and Salmonella typhi [2]. North Sumatera is the central production of purple passion fruit in Indonesia. Passion fruit was processing into beverage product that produced passion fruit pericarp waste. The passion fruit pericarp has potential effect as a sources of medicine which is need to be examined such as its antibacterial effect. It is necessary to determine antibacterial activity of ethanol extract of purple passion fruit pericarp (Passiflora edulis Sims.) on Staphylococcus aureus dan Escherichia coli.

\section{Materials and Methods}

\subsection{Materials}

The materials used in this study were purple passion fruit pericarp, nutrient agar, nutrient broth, distilled water, Staphylococcus aureus ATCC 25923 and Escherichia coli ATCC 25922.

\subsection{Plant identification}

Fresh fruit of Passiflora edulis Sims were collected in Central Market of Medan, Indonesia. The sample was identified at Indonesian Institute of Science, Research Center of Biology, Bogor, Indonesia. Authentification number 440/IPH.1.01/lf.07/IV/2015

\subsection{Extraction of Passion Fruit pericarp}

An amount of $300 \mathrm{~g}$ dried material plant samples were crushed in a blender, then macerated in ethanol $96 \%$ for 3 hours thereafter moved to perlocator tube. Percolation was stopped if the last $500 \mathrm{mg}$ of solvent were evaporated, leaving no residuals. The solvent was evaporated at low pressure with a temperature of not more than $40^{\circ} \mathrm{C}$ using a Rotary evaporator. 


\section{4. screening of the Phytochemical simplicia and ethanol extract of Passion Fruit pericarp}

Phytochemical simplicia and ethanol extract of Passion Fruit pericarp included examining the chemical secondary metabolites of alkaloids, flavonoids, glycosides, tannins, saponins, triterpenoids, and steroids [3-5].

\subsection{Preparation of Bacterial Inoculum}

Bacterial colonies were taken from the culture stock with a sterile ose needle then suspended in a test tube containing $10 \mathrm{ml}$ of nutrient broth media, then the turbidity of the solution was measured at a wavelength of $580 \mathrm{~nm}$ until a $25 \%$ transmittance was obtained which was equivalent to $10^{6} \mathrm{CFU}$ (Colony Forming Units) [6].

\subsection{Preparation of Extract Solution Test}

As much as $1 \mathrm{~g}$ of ethanol extract of passion fruit pericarp was carefully weighed with an analytical balance. The extract was dissolved ad to $2 \mathrm{ml}$ DMSO solvent in a vial and obtained extract concentration of $500 \mathrm{mg} / \mathrm{ml}$. The solvent was diluted to several concentrations of 400 , $300,200,100,75,50,25,12.5$ and $6.25 \mathrm{mg} / \mathrm{ml}$.

\subsection{In Vitro Antibacterial test}

The bacteria inoculum as many as $0.1 \mathrm{ml}$ was put into a petri dish, then added $20 \mathrm{ml}$ of nutrient agar waited until the temperature reached $45^{\circ} \mathrm{C}$, homogenized and left it until the media become a solid form. Furthermore, paper discs (diameter of $6 \mathrm{~mm}$ ) were immersed in extract solution on various concentrations, dried and placed on the surface of the agar media. The media was incubated at $36-37^{\circ} \mathrm{C}$ for $18-24$ hours. The diameter of the inhibitory area around the paper disc was measured using a calipse. The test was carried out 3 times [6].

\section{Results and Discussion}

\subsection{Phytochemical screening result of simplicia and ethanol extract of purple passion fruit}

The qualitative test of phytochemical properties on simplicia and ethanol extract of purple passion fruit pericarp showed in table 1 .

Table 1. Phytochemical screening of simplicia and ethanol extract purple passion fruit pericarp

\begin{tabular}{clcc}
\hline No. & Phytochemical properties & Simplicia & Ethanol extract \\
\hline 1. & Alkaloids & - & - \\
2. & Flavonoids & + & + \\
3. & Glycosides & + & + \\
4. & Anthraquinone glycosides & - & - \\
5. & Saponin & + & + \\
6. & Tannin & + & + \\
7. & Steroids/Triterpenoids & + & + \\
\hline
\end{tabular}


where:

(+) positive: contains a class of compounds

(-) negative: does not contain compounds

Table 1 showed that the simplicia and ethanol extract of purple passion fruit pericarp had several compound such as alkaloids, flavonoids, glycosides, anthraquinone glycosides, saponin, tanin and steroids/triterpenoids. Flavonoids, tannin, saponins and steroids / triterpenoids are phytochemical compounds that have potential effect as antibacterial and antiviral agents.

\subsection{Antibacterial test of purple passion fruit pericarp ethanol extract}

The results of the measurement of the inhibiting diameter of bacterial growth area Staphylococcus aureus and Escherichia coli can be seen in the table 2.

Table 2. Antibacterial acticity of ethanol extract of purple passion fruit pericarp

\begin{tabular}{llllllllll}
\hline & & \multicolumn{6}{c}{ Diameter of Inhibition area $(\mathbf{m m})$} \\
\cline { 3 - 10 } No. & $\begin{array}{c}\text { Concentration } \\
(\mathbf{m g} / \mathbf{m l})\end{array}$ & \multicolumn{3}{c}{ Staphylococcus aureus } \\
& & D1 & D2 & D3 & Mean & D1 & D2 & D3 & Mean \\
1. & 500 & 16,9 & 16,8 & 16,9 & 16,86 & 16,7 & 16,6 & 16,8 & 16,7 \\
2. & 400 & 15,8 & 15,7 & 15,9 & 15,8 & 15,8 & 15,6 & 15,6 & 15,66 \\
3. & 300 & 14,6 & 14,6 & 14,8 & 14,66 & 14,5 & 14,4 & 14,6 & 14,5 \\
4. & 200 & 13,3 & 13,5 & 13,6 & 13,46 & 13,5 & 13,6 & 13,4 & 13,5 \\
5. & 100 & 12,5 & 12,6 & 12,4 & 12,5 & 12,5 & 12,4 & 12,4 & 12,43 \\
6. & 75 & 10,5 & 10,6 & 10,5 & 10,53 & 10,3 & 10,4 & 10,4 & 10,36 \\
7. & 50 & 7,1 & 7,2 & 7,4 & 7,23 & 8,4 & 8,6 & 8,3 & 8,43 \\
8. & 25 & - & - & - & - & - & - & - & - \\
9. & 12,5 & - & - & - & - & - & - & - & - \\
10 & 6,25 & - & - & - & - & - & - & - & - \\
10. & Blank & - & - & - & - & - & - & - & - \\
\hline
\end{tabular}

where:

$\mathrm{D}:$ diameter $(\mathrm{mm})$

The concentration of extract which fulfill the requirements of Ditjen POM (1995), is the concentration of extracts with an effective inhibition area of approximately 14-16 $\mathrm{mm}$ [6]. The results of antibacterial activity of ethanol extract on Staphylococcus aureus and Escherichia coli showed an effective inhibition at the concentration of $300 \mathrm{mg} / \mathrm{ml}$ with an effective inhibition diameters were 14.66 and $14.5 \mathrm{~mm}$, respectively. Minimum inhibition concentration of ethanol extract against Staphylococcus aureus and Escherichia coli at the concentration of $50 \mathrm{mg} / \mathrm{ml}$ with inhibitory diameter of $7.23 \mathrm{~mm}$ and $8.43 \mathrm{~mm}$ respectively. Ethanol extract of passion fruit pericarp had an effect in inhibiting the growth of Staphylococcus aureus and Escherichia coli bacteria due to its phytochemical properties that had strong antibacterial activity, namely flavonoids, tannins saponins, and streroids / triperpenoids.

Tannins are phenol compounds that are widely distributed in vascular plants. Phenol compounds and their derivatives were one of the antibacterials that works by disrupting the 
function of the cytoplasmic membrane. Low concentrations of phenol compound could damage the cytoplasmic membrane which causes leaking of metabolites that is important in bacterial enzyme system, while at high concentrations, it could damage the cytoplasmic membrane and proteins of cell $[5,7]$. Saponins are used as antimicrobials in recent years. The mechanism of action of saponins as antibacterials is to reduce surface tension resulting in increased permeability or leakage of cells, it resulting dicharge of intracellular compounds [8]. Steroids and triterpenoid also have antibacterial activities. Some studies reported antibacterial activitiy of steroid and triterpenoid againts several bacteria [9-11].

The results showed that the Staphylococcus aureus bacteria had a greater inhibitory zone compared to Escherichia coli bacteria in various concentrations of the test solution. The difference was occured because both bacteria species have different composition and cell wall structure. Gram-positive bacteria more susceptible to chemical compounds than gram-negative. The cell wall structure of gram-positive bacteria is simpler, it has single-layered with a low lipid content (1-4\%) making it easier for bioactive ingredients to enter the cell. The structure of cell wall of the gram-negative bacterial is more complex, it has three-layered consisting of the outer layer of lipoprotein, the middle layer of lipopolysaccharide which acts as a barrier to antibacterial bioactive material, and an inner layer of peptidoglycan with high lipid content (11$12 \%)[12-14]$.

\section{Conclusion}

Antibacterial activity of ethanol extract of purple passion fruit pericarp on Staphylococcus aureus and Escherichia coli shows an effective inhibition at the concentration of $300 \mathrm{mg} / \mathrm{ml}$, and the effect shows dose dependent manner.

\section{Acknowledgment}

The authors thanks to Faculty of Pharmacy, University of Sumatera Utara for providing this research.

\section{REFERENCES}

[1] B.O. Akanbi, O.D. Bodunrin, S.Olayanju, "Phytochemical screening and antibacterial activity of Passiflora edulis", Researcher, vol.3, no.5, pp.9-12. 2001.

[2] J. M. Nicolls, J. Birner, and P. Forsell, "Passicol, an Antibacterial and Antifungal Agent Produced by Passiflora Plant Species: Qualitative and Quantitative Range of Activity," Antimicrobial Agents and Chemotherapy, vol. 3, no. 1, pp. 110-117, Jan. 1973.

[3] Ministery of Health of Indonesia, Materia Medika, 6th Edition. Jakarta, p. 297-307. 1995.

[4] N.R. Farnsworth, "Biologycal and phytochemical screening of plants". J Pharm Sci, vol. 55, no.3, pp. 225-76. 1996.

[5] J.B. Harbone, Phytochemical Method, ITB. p. 49.1987

[6] Directorate General of Drug And Food Control, Indonesian Pharmacopoeia, Edition IV, Ministry of Health of Indonesia,p. 891 - 898, 1035.1995 
[7] M. J. R. Vaquero, M. R. Alberto, and M. C. M. de Nadra, "Antibacterial effect of phenolic compounds from different wines," Food Control, vol. 18, no. 2, pp. 93-101, Feb. 2007.

[8] P. Mandal, S. P. Sinha Babu, and N. C. Mandal, "Antimicrobial activity of saponins from Acacia auriculiformis," Fitoterapia, vol. 76, no. 5, pp. 462-465, Jul. 2005

[9] A. Nick, A. D. Wright, O. Sticher, and T. Rali, "Antibacterial Triterpenoid Acids from Dillenia papuana," Journal of Natural Products, vol. 57, no. 9, pp. 1245-1250, Sep. 1994.

[10] X.T. Liu, A. Winkler, W. Schwan, T. Volk, M. Rott, and A. Monte, "Antibacterial Compounds from Mushrooms II: Lanostane Triterpenoids and an Ergostane Steroid with Activity AgainstBacillus cereusIsolated fromFomitopsis pinicola," Planta Medica, vol. 76, no. 05, pp. 464-466, Oct. 2009.

[11] S.-G. Liao, L.-J. Zhang, F. Sun, J.-J. Zhang, A.-Y. Chen, Y.-Y. Lan, Y.-J. Li, A.-M. Wang, X. He, Y. Xiong, L. Dong, X.-J. Chen, Y.-T. Li, L. Zuo, and Y.-L. Wang, "Antibacterial and anti-inflammatory effects of extracts and fractions from Polygonum capitatum," Journal of Ethnopharmacology, vol. 134, no. 3, pp. 1006-1009, Apr. 2011.

[12] T.J Beveridge, "Structures of gram-negative cell walls and their derived membrane vesicles" Journal of bacteriology, vol 15, no. 181(16), pp. 4725-33, Aug. 1999.

[13] A. M. Fayaz, K. Balaji, M. Girilal, R. Yadav, P. T. Kalaichelvan, and R. Venketesan, "Biogenic synthesis of silver nanoparticles and their synergistic effect with antibiotics: a study against gram-positive and gram-negative bacteria," Nanomedicine: Nanotechnology, Biology and Medicine, vol. 6, no. 1, pp. 103-109, Feb. 2010.

[14] M. R. J. Salton, "The nature of the cell walls of some gram-positive and gram-negative bacteria," Biochimica et Biophysica Acta, vol. 9, pp. 334-335, Jan. 1952. 